\title{
Urban rivers in Belgrade, Serbia. Radical transformations and illegal urban practices in a post-socialist capital
}

Fiumi urbani a Belgrado, Serbia. Trasformazioni radicali e pratiche urbane abusive in una capitale post-socialista

\section{Sanja Iguman}

\section{(2) OpenEdition Journals}

Electronic version

URL: https://journals.openedition.org/aam/4334

DOI: $10.4000 /$ aam.4334

ISSN: 2038-3215

Publisher

Dipartimento Culture e Società - Università di Palermo

\section{Electronic reference}

Sanja Iguman, "Urban rivers in Belgrade, Serbia. Radical transformations and illegal urban practices in a post-socialist capital", Archivio antropologico mediterraneo [Online], Anno XXIV, n. 23 (2) | 2021, Online since 31 December 2021, connection on 08 January 2022. URL: http://journals.openedition.org/aam/ 4334 ; DOI: https://doi.org/10.4000/aam.4334

This text was automatically generated on 8 January 2022 .

\section{(c) $(1) \odot$}

Archivio antropologico mediterraneo è distribuita con Licenza Creative Commons Attribuzione - Non commerciale - Non opere derivate 4.0 Internazionale. 


\title{
Urban rivers in Belgrade, Serbia. Radical transformations and illegal urban practices in a post-socialist capital
}

\author{
Fiumi urbani a Belgrado, Serbia. Trasformazioni radicali e pratiche urbane \\ abusive in una capitale post-socialista
}

Sanja Iguman

\section{Introduction}

1 Regardless their geographical location, most people around the world are witnessing radical urban transformations: empty spaces are being turned into packed places; the shapes of inhabited places are being radically changed; landscapes are being permanently transformed and destroyed; green areas are being-turned into grey concrete areas. According to the report by the United Nations Department of Economy and Social Affairs ${ }^{1}$, around 2.5 billion people will be living in cities by 2050, which puts urban areas in a dominating position in terms of impact over the economic, social and political world scenarios. The impact of urbanization has caused the reconfiguration of the spatial economy, with severe consequences on cities and communities, putting the latter in a strategic position for developing an analysis of global processes (Sassen 1996). One of the burning issues in urban analysis has become the exploitation and over-consumption of commons and shared resources, which has made cities a stage of political struggles against privatization of public spaces and the reduction of social services (Mattei, Quarta 2015). These notions become even more alarming if we consider that human beings are now living in the so-called Anthropocene and that extreme consequences of the human driven climate change, characterizing the Anthropocene, are particularly visible in urban areas, which become fragile and risky spaces, as it is observed on a daily basis (Bougleux 2017). Therefore, it is of paramount 
importance to consider the city as a complex assemblage of human and nonhuman entities that interact thanks to the urban proximity, and equally demand attention and concern. In fact, nonhuman entities have been progressively manipulated by humans through history, culture, art, technology and through these processes they have been that way urbanized into the city as we know it today (Bonadei 2009).

2 A particular segment of the city of Belgrade is the focus of the present study, the Sava river and its riverbanks. When exploring the anthropological approach on the notion of rivers, we realize that they are neither natural nor cultural entities, but rather entanglements of both, and this thought goes back much further into the past, contradicting common-sense notions of rivers as something purely natural. Since time immemorial, human beings have been transforming rivers in many ways in order to use them, by building bridges, dams, channels, etc., or to simply enjoy them by developing facilities on the riverbanks or in the water. On the other hand, rivers have influenced people's lives in harmful ways as well, when they flooded the settlements, bringing destruction and death. Consequently, rivers and the relation they have with the people living around them should be studied in a multidisciplinary perspective (Edgeworth 2011).

3 Therefore, it does not surprise that the "natural" riverbank is an important mean for constructing city`s landscapes: flowing water, soil, vegetation, and animals make rivers and their riverbanks a dynamic landscape, which is different from the stagnant, concrete structures in the rest of the city. This explains why rivers and their banks are so attractive to greedy investors and in some cases to governments: waterfront developments have become a dominant theme of urban regeneration globally when it comes to urban regeneration of cities (Brownhill 2013). Rivers represent a great resource for investment, both in cultural and natural sense: a possible experience of riverine 'nature' revolves around tourism and leisure, as well as the pursuit of pleasure, for the search of aesthetically pleasing environments. Indeed, residential areas close to river banks have always been attractive for citizens, therefore interesting for both investors and buyers (Prideaux et al. 2009).

Due to the strong impact of some of the mentioned human activities during the process of urbanization, urban rivers have become extremely anthropized spaces, and quite often seriously endangered by the same process of anthropization, so that the lives of people and animals around them do not benefit from the river presence anymore, as in the case of Sava in Belgrade. The problem is even bigger when the anthropic transformations are too radical, too aggressive or even illegal: in the case of the present study the existing urban and natural protection laws are being ignored, police and inspections are not reacting to citizens' complaints, safety of the citizens is jeopardized by forbidden activities that are left thriving despite the laws. When all this occurs, a direct clash between governments, investors and local citizens is inevitable, especially because it usually means that there has been a severe lack of citizens' participation in all processes of decision making.

\section{The setting}

5 A suitable example for discussing previously mentioned phenomena and social dynamics is the riverine space in Belgrade. The location of the city is marked off by two international rivers - the Sava, the Danube and their confluence - Usce, in Serbian. In 
this place the three different elements of water, stone/sand and wood constitute a peculiar geomorphologic set that has moulded a solid city foundation over the centuries, allowing humans to build various urban structures within a formerly "natural body" - in process of co-development crucial for the birth and development of Belgrade (Cvijic 2013).

Due to its turbulent history, Belgrade has been built, destroyed and rebuilt many times, which can easily be seen in the many "scars" left on its urban tissue. The last very problematic period for Belgrade was during the Nineties, when it went through a drastic economic and political deviations and also a forceful destruction, culminated with the NATO bombing in 1999. The last twenty years were marked off by a longlasting transition that had a strong impact on all segments of life in Belgrade. One of the most significant urban phenomena in Serbia over the past thirty years has been the rapid and extensive growth of illegal construction. Although roots of this occurrences could be traced back in the socialist housing policies, all the way along the 1970s and 1980s, changing socio-economic and political conditions during the transitional period in Serbia after the 2000 provided a new set of reasons and motivations for the spread of illegal constructions (Grubovic 2006).

7 The river Sava and its riverbanks have probably been the most mishandled location in Belgrade in the last decade. Although there are several mega-projects that have already begun or are being planned around the confluence and/or along the Sava`s riverbanks (The Belgrade Watefront ${ }^{2}$, Kalemegdan cable-car ${ }^{3}, \mathrm{~K}$ district ${ }^{4}$, just to name the most significant ones) $)^{5}$, this paper focuses on the riverbank of Sava as it flows through the largest municipality in Serbia, New Belgrade, Novi Beograd, analysing both socially and spatially a small-scale but very intense and rapid illegal constructions that are happening there (Picture 1).

8 The river Sava is a significant transnational river, which can be confirmed in The Sava River Basin Analysis Summary ${ }^{6}$ : it is the longest tributary $(945 \mathrm{~km})$ to the Danube River with $95.551 \mathrm{~km} 2$ large catchment. Its drainage basin is a major one of the Balkans and of the entire Southeastern Europe. The river Sava flows through Slovenia, Croatia, Bosnia and Herzegovina and Serbia, but its basin area belongs also to Montenegro and insignificantly to Albania. Population in the Sava River Basin represents $46 \%$ of the total population of all crossed countries, excluding Albania and Montenegro.

Next to the river Sava in Novi Beograd, a Belgrade`s municipality, residential areas are constituted by the so-called blokovi, blocks, complexes with a peculiar role in the city since their very beginning, after the Second World War. Tito`s idea was that Novi Beograd develops as a multifocal part of the city - symbolic and functional, by hosting new and important government structures as well as to address the most pressing issue of modern socialist Yugoslavia - the housing issue (Le Normand 2014). The mentioned blocks were constructed with the idea of being a "dormitory" and carrying as many apartments as possible, which made Novi Beograd the most populated municipality of Serbia. (Nicic, Iguman 2019).

10 The blocks are spread in the area along $2.3 \mathrm{~km}$ quay of the river Sava and they are home to almost 100,000 people (Picture 2). The quay was built at the end of the Eighties, after the completion of the construction of the blocks and it was planned to be a green oasis for the residents, in the convincing perspective that being positioned next to the river was still a privilege. More than $80 \%$ of the area is still covered with public, green parks and pedestrian zones. In socialist and communist systems such as Yugoslavian 
one, public spaces were a prerogative of the people, not intended to provide increase of capital, which is why enormous green areas and wide quays along the rivers were of utmost importance in urban planning (Le Normand 2014). However, neoliberalism transformed the meaning of the whole urban structure, hence, the blocks and Sava's riverbank as well. Along the riverbank, private properties and floating objects have appropriated the public spaces, being permanently docked to the riverbank. The floating objects are restaurants, bars, night clubs, hostels, and private services for leisure, called splavovi, literally a raft.

11 The first "floating object" ever in Belgrade was Savski Galeb, a restaurant set up in 1987, right in the mentioned area. During the Nineties, the number of splavovi was steadily raising, showing a "success" which continuously kept rising. Then, in the last several years, the situation drastically deteriorated: there are too many "floating objects" that cause a drastic pollution of the water and the riverbank. In the moment of writing this paper, there are 89 floating objects along 2.3 kilometres of the Sava's riverbank, which leaves only 400 meters of free riverbank as public and common space ${ }^{7}$. Most of these floating objects have never received permissions to stay docked nor to float in the river from authorities of urban planning, nor sanitary, nor touristic and water inspections. Local authorities know about the generalized lack of authorizations and confirm it on a daily basis in the media. They are constantly giving promises that the problem will be solved, however nothing changes. The appropriation of the Sava's quay has had an enormous impact on the people who have been living in the area since its construction, in the Seventies and the Eighties, but the impacts of illegal docking and business along the river is much wider.

The multidimensional problems that the local citizens are facing can be sketched as (Pictures 3 and 4):

- Environmental: air, soil, water and noise pollution. Owners/workers of the splavovi throw the waste directly into the river; green areas are mishandled by cars, although the traffic is forbidden in that area; working hours are not respected, so extremely loud music is unbearable in the neighbourhood in the night.

- Legal: most of the splavovi have illegal infrastructures: they do not have permissions nor licences for being there and operating as bars, restaurants, etc.

- Safety issues: the splavovi are not authorized to use water and electricity supply systems. Electric cables and water pipes are illegally drawn and hanging over pedestrian paths and tied to trees and electrical poles. As mentioned, there is cars' traffic in pedestrian zones although it is forbidden, which all make this area dangerous for pedestrians and cyclists.

However, according to locals` and activists` interviews in newspaper, on the radio, TV, social networks or surveys, the biggest problem for the most locals is immaterial: their favourite landscape has been destroyed and they cannot see the river anymore, because the view has been blocked by too many, too large and never moving floating objects. A very interesting survey was conducted in 2020, by a local activist group Za nas kej/For our quay and was filled out by 2000 people $^{8}$. The most common reaction to this survey was their anger for being prevented to see the river from the riverbank, especially by those people who compared the current situation to the one from the Eighties, when they moved to the blokovi and when the quay was constructed.

This does not surprise at all, if we consider the significance that a certain landscape might have for people. Landscape is an ambiguous term and concept which is used both 
in practical, daily discourses and in academia, oscillating from very precise notions to quite abstract ones. Landscape is seen across various disciplines from landscape ecology and geography to anthropology and art history, just to name a few. The definition that I find right for understanding why the destroyed landscape of the river Sava is the biggest problem for citizens living in that area, is the one given by Ingold (2012: 241):

Landscape is a multi-layered concept: it includes nature in the meaning of earth, water, plant and animal life, biological and geological diversity; it includes humanmade objects, buildings, roads, sculptures, the products of culture; it also includes movements and action. But on top of all these visible phenomena, landscape includes the invisible. The invisible relationship which emerges in people's actions, movements, speech, thoughts, imaginations and narratives are intertwined with the visual; they emerge in an interaction with the visual.

The Ingold's "invisible relationship" confirms the fact that people attach themselves to places that leave traces on them, that way influencing their sense of identity. Personal or even collective identity is strongly supported by the sense of place - place being the central element of embodied experience, the synthesis of self, space and time (Feld, Basso 1996). This attachment to a certain place comes from memory, a crucial part for creation of any kind of identity - be that personal or collective one. In the case of disappointed citizens who evoke memories of their neighbourhood as it once was, we speak of an individual memory - nostalgia, which originates from the lived experiences (Lowenthal 1995). These experiences are repeatedly confirmed in the survey by Za nas $k e j$, in which people retell their special moments from the childhood and youth, emphasizing the importance of the events` place - the Sava`s riverbank.

There is another, more existential problem, located upstream of the mentioned quay, towards the Belgrade`s municipality of Obrenovac, in the area which is not supposed to be settled nor urbanized according to the law (Law on Waters, Spatial Plan for the Republic of Serbia, 2010), as it hosts water supply and drainage systems ${ }^{9}$ : Ranney ${ }^{10}$ and tubular collectors in this area collect the underground water from the gravel-sand aquifer and supply Belgrade and its 1.7 million citizens with a high-quality drinking water. For this reason, it is very important to maintain strict sanitary protection of the gravel-sand aquifer characterizing this environment from permanent pollution and degradation. However, hundreds of houses have been illegally built in the floodplain area of the Sava river, from the blocks to the Ostružnica bridge (half way between the blocks and Obrenovac) in 2008 and in 2009 (Picture 5). Construction of solid buildings in the floodplain is strictly forbidden, as it obstructs the protection barriers and increases the risk of floods (Law on Waters, Spatial Plan for the Republic of Serbia, 2010). In this particular zone more than 100 thousand people are imperilled by floods, i.e. the people living in the previously mentioned residential blokovi. At the same time, these houses are in the close proximity to 16 out of 99 Belgrade water collectors that purify the water for entire Belgrade and its surroundings. Numerous cars and trucks illegally drive along the road which runs on the embankment that was built only for the vehicles of companies in charge of maintaining the embankment and the water collectors. The unregulated use of the flood barrier is strictly forbidden by the Serbian Law of Water, since it is gradually demolishing the entire flood embankment. 


\section{The actors} intensive and illegal transformations of their neighbourhoods that is rapidly bringing to the environmental devastation of the city surrounding them, a brief insight in the analysis of social engagement in Serbia is needed. Being a post-socialist country, and one of the main actors in the creation of economic, cultural, social and political chaotic dynamics in the Nineties in ex-Yugoslavia, Serbia had quite a low level of noninstitutional social engagement and was generally characterized as undeveloped civic society in that sense. In the transition period the idea of a liberal civil society, supported by foreign investments and donations, aimed primarily at representation of different interests within the political decision-making process and participation in policy formulation. Civil society organizations were supposed to become partners of the state in implementing neoliberal agendas conducting activities in the domains of social policy. However, that context could not bear authentic civic activism or spontaneous social movements based on common values and autonomy that is usually shared on a local level (Fiket, Pudar Drasko 2021).

Still, recent studies show that the situation in the last five years has been rapidly changing towards increased use of non-institutional channels and instruments of political participation such as protests and social movements. Citizens' trust in political parties is declining sharply, while on the other hand, local initiatives and movements are becoming louder than ever (Fiket, Pudar Drasko 2021). Certainly, this entails gatherings in a virtual space as well, but nevertheless, the voices have been raising more and more intensively, which can be easily confirmed observing the daily virtual activities in Belgrade, and in entire Serbia as well.

reason for such a tendency is the noticeably high level of dis-trust in the state institutions which are turning "a blind eye" to illegal practices, such as construction and housing regardless of the innumerable complaints by local citizens, narrowing down to the present topic and the case study. In such situation, citizens are "forced to take things into their own hands" which implies various initiatives, from organizing imperceptible neighbourly activities, over protesting on a small and large scale, all the way to becoming official organizations or movements, even preparing a candidacy for the next elections. This way a local political movement Don't Let Belgrade D(r)own (Ne da(vi)mo Beograd ${ }^{11}$ was born.

20 Although Serbia is characterized by a high dis-trust in public institutions, when reacting against a particular illegal construction or disruption of a public space, most citizens first turn precisely to those institutions with their complaints. There is a certain pattern that is even advised by committed experts who work on education of citizens on "how to defend space" (Aksentijevic et al. 2021). Practically always, the first step of a protest is collecting signatures, and address them for official complaint to the Secretariat for Urban Planning and Construction in Belgrade. These complaints are usually written by experts who are either activists or someone who is closely working with them. This big democratic effort rarely solves the matter or, unfortunately, even has any point. In case of a negative outcome, usually the following step is the gathering of neighbours (and also citizens from other parts of Belgrade, if the problem is not only local) and protesting in a visible way in the public space; or literally defending a certain space in the physical sense, i.e. stopping a construction site. In this case, also the media 
takes a relevant role and then, depending on many different circumstances, the announced construction is stopped or at least paused. But in the case that I previously described- the left riverbank of Sava, none of citizens` reaction had any noticeable effect on the institutions so far.

21 Another related motive for Serbian citizens' growing engagement might be traced in solidarity, which is growing in some ex-Yugoslav countries in support of each other: for example, when helping victims of disastrous flooding in 2014 in Croatia, Bosnia and Herzegovina and Serbia, or helping migrants crossing the Balkans, or raising money for sick children's treatments abroad ${ }^{12}$, etc. These solidary actions prove both the enthusiasm of citizens to help each other, especially when sharing the same problem, as well as incompetence or unwillingness of state institutions to offer crucial support in some cases (Vasiljevic 2019). This assertion comes from the direct experience, but sometimes they also originate from the open confessions of Belgrade`s authorities (city's architect, mayor, vice mayor and others), who give statements to media on a daily basis, in which they admit the existence of the problem, declaring at the same time the reasons for not solving it. Usually among these reasons there are a bureaucratic obstacles, lack of will to take responsibility, lack of financial resources, but most often, the reason for not solving some problem is because "it derives from the previous regime, which means that it takes time to be solved". Actually, the present government has been in power for almost a decade now.

One more reason to frame the growing of citizens' dis-trust in institutions lies in the fact that the Serbian government is openly against citizens' participation in any kind of decision-making, which immediately creates dis-functional relations among them and increases the lack of trust. One of the countless examples to support this, comes from the activists' group Za nas kej: members of the group have written countless letters to various institutions authorised for all matters related to the river Sava, its riverbank, the quay and the surroundings, asking to be involved in problems solving and decision making. No request was ever answered.

\section{Personal position on the field}

I live in one of the mentioned blocks, five minutes walking from the Sava's riverbank, consequently I have a good insight in daily issues and happenings in situ, as well as a direct, daily contact with neighbours and local activist groups. My position on the field is rather fluid, varying from a passive observer, across an involved academic who is often a link between neighbours acting on the field and the academic community that theoretically supports these issues, all the way to an activist - a member of an informal citizens' group Za nas kej that has more than 3.000 followers on Facebook and around 20 active members. Thanks to this multi-dimensional position, I constantly develop a complex spectre of perspectives that help me understand the situation holistically, that way using the ethnographic method as a link between my activism and its theoretical framework. The lived experience together with the observational approach supports my research, which combines qualitative method (unstructured interviews, conducted in a free form of daily conversations with neighbours, both in virtual and real world) as well as the quantitative one (the previously mentioned survey with a sample of 2000 neighbours. 

a bigger visibility and therefore the possibility to step out of their neighbourhood, to create a network with more actors of different scales and type. Exactly as the program suggests, the community became active, awaken and involved through and thanks to the realization of this project. It is quite clear that once some actor leads the way, all people who feel certain solidarity or similar emotions towards a shared heritage or place become willing to engage personally, in a movement or an activity. Some of the comments the group of activists received from the local citizens during the festival, as well as afterwards on the social media are the following: "Finally someone pointed out at the problems in our community."; "We are happy that someone involved us and our children in matters that concern us"; "Educational events like this one should be organized on a regular base.", etc.

my personal experience is considered, I was the coordinator of the second project and one of the organizers of the first one. These positions provided me with a valuable insight for understanding how an activist group functions in practice, how community reacts when it becomes directly involved in such projects, what are the weaknesses and strengths of activist groups. One of the most important lessons learned 
is the existence of a sharp difference between virtual and real activism, something that becomes obvious only when the words need to be turned into action.

The difference I point out is particularly interesting if we consider the rise of the virtual activism at this historical moment. Digitization and globalization have brought a major chance in participation practices: digital tools and social media have become the main instruments both for communication and for information circulation. Hence it does not surprise that people have become more aware of the world around them, which brought to the higher level of engagement in discussions in virtual world. Serbia is a country with the limited freedom of media ${ }^{17}$, which means that the main source for getting news different from those in the mainstream, national media are social networks. Practically all news, announcements, invitations to protests by activist groups, NGOs and most of the political parties happen on Facebook or Twitter in Serbia, which shows the importance of digital communication at the moment. However, the engagement in virtual world is not comparable to the one in the real world and most people`s reaction are limited to their comments or posts on social networks.

Za nas kej is not an isolated experience: besides them there are other groups gathered around the same aim, i.e. the protection of the Sava`s riverbank: Savski nasip with their 110.000 Facebook followers and Blok 70 - Zajednicka akcija, with more than 4.000 Facebook followers, and others, less influential and active groups. Although the largest part of activities and communication among these groups refers to virtual dimension of Viber, Facebook, Twitter and Instagram, these groups are actively present on the field: planting and watering trees, setting up a local recycling system, cleaning the neighbourhood, dealing with the daily, communal issues, submitting objections to various problems, referring to media on the burning topics, etc. An interesting fact is that all mentioned groups recognize each other, officially support each other, but rarely cooperate in practice. In my view, as someone who is present in most of the group`s activities, this fact has been proved to be disadvantageous on many levels.

An interesting twist happened when 14 activist groups in Belgrade gathered under the Joint initiatives and movements - ZIP, in order to act together when the problem is not only local, but on the city's level, or even regional and national. This has happened recently, therefore it is too early to analyse this cooperation. Momentarily, most of these groups are discussing their positions and potential collaborations at the local and parliamentary elections that will take place in spring of 2022 in Serbia. Also, big events regarding ecological threats in Serbia have brought these groups closer to each other in 2021, when they organized several large protests against air pollution, the announcement that the world famous company Rio Tinto will set up lithium mine in Western Serbia ${ }^{18}$ and the privatization of "Jaroslav Černi", the leading Serbian scientific research institute for water ${ }^{19}$.

\section{Conclusion}

31 Insufficient civic education, systemic lack of trust in the institutions, fear of exposing themselves, are only some of the problems that abate social engagement in countries with the political, economic and social settings such the one in Serbia. Nonetheless, in recent years significant scholarly and academic interest in this topic has arose in the country. The Institute for Philosophy and Social Theory (University of Belgrade) places the studies of public and political engagement at the centre of its research activities, 
trying to provide qualitative insights on the topic of social engagement that might improve the Serbian scenario on that matter, particularly regarding the trust/dis-trust relation with governance. The Laboratory for Active Citizenship currently running in the mentioned Institute is committed to the interdisciplinary study of citizens' participation in public life as well as to the active promotion of participatory citizenship, as an indispensable element of a democratic society. At the moment of writing this paper, the Institute is launching a new Laboratory for Theory, Creation and Politics of Space, which will be dealing with urban commons, environmental issues, involvement of citizens in their city's transformations, both at theoretical and activists' level. Also, the Institute`s international network is comprised mostly of left-green oriented experts, organizations and institutions, which puts Belgrade and Serbia in the fruitful position of benefiting from the engaged collaborators, that could support Serbia in catching the ongoing green wave in Europe, at least in academic context.

32 Another international framework that sees Serbia linked to the left-green side of European political and activist scenario is activated by the previously mentioned political movement Ne da(vi)mo Beograd. The movement has been supported by leftgreen parties and coalitions across Europe, as well as by movements that share similar problems and visions, like the ones that won the last elections in Croatia (Mozemo) and in Montenegro (URA). This is a particularly interesting sign seen in the perspective of past decades, marked by long-lasting political disagreement among ex-Yugoslav republics. Ne da(vi)mo Beograd's strongest feature is the bottom-up approach in their activism and the participatory program they are proposing. They are the only party in Serbia that was born from an activist group, then recognised at larger social scale thanks to their street activities and the numerous, big protests they organized in the last five years.

33 I optimistically believe that this ongoing wave of activism in Belgrade and the rest of Serbia as well, could be a step towards a more significant democratic participation of citizens in decision-making. This engagement particularly addresses environmental and urban issues in Serbia, which is, I would dare to say, tragic. Hopefully, as that situation keeps deteriorating, the social engagement will proportionally grow. Moreover, previously mentioned academic and political channels seem to provide a certain support - within their own limits and frameworks, but still quite significant, considering the broader context of rising populism and dis-trust in democracy and governmental institutions abroad and also in Serbia.

As far as my involvement is concerned, for someone who is both an academic and an activist, there are many challenges in keeping both worlds vigorous and none of them neglected. There is a common belief that these two worlds should be kept separated, which is an assumption mostly based on questionable rational dichotomies such as theory/practice, reason/emotion, abstract/concrete, etc. However, my position acrossworlds provides also some benefits - it allows a glimpse into the "real" and a continuous verification process, not so granted for an academic, and on the other hand an easier appropriation of theoretical frameworks to support activism. The importance of urban rivers both for cities`environment and for lives of citizens is a quite clear issue. The ongoing transformations along the river Sava and their impacts on the community living in that area, as well as the community's reaction, has become a burning issue in Belgrade, increasing in the last few years. Hopefully, the activist 
groups, with the rising political and academic support will get their civic rights back and have their voices heard.

\section{BIBLIOGRAPHY}

Aksentijević M., Stojić B., Timotijević, J., 2021 Priručnik za odbranu prostora, Ministarstvo prostora/ Institut za urbane politike, Beograd.

Bougleux E., 2017 «Incertezza e cambiamento climatico nell'era dell'Antropocene» in EtnoAntropologia. V, Issue 1: 79-94.

Bonadei R., 2009 Naturaleartificale. Il palinsesto urbano, University of Bergamo, Lubrina Editore, Bergamo.

Blok 70 - Zajednička akcija - Facebook

https://www.facebook.com/ZajednickaAkcijaB70 (last accessed Aug 16, 2021).

Brownhill S., 2013 «Just Add Water: Waterfront Regeneration as a Global Phenomenon» in M. E. Leary, McCarthy (ed.), The Routledge Companion to Urban Regeneration, Routledge, Abingdon: 45-55.

Cvijić J., 2013 Balkansko poluostrvo i južnoslovenske zemlje, Narodna Biblioteka Srbije, Beograd.

Edgeworth M., 2011 Fluid Pasts: Archaeology of Flow, Bloomsbury Academic, Bristol.

Feld S., Basso K.H., 1996 Senses of place, School of American Research Press, Santa Fe.

Fiket I., Pudar Drasko G., 2001 «Possibility of non-institutional political participation within the non-responsive system of Serbia: The impact of (dis)trust and internal political efficiency» in Sociologija, LXIII, Issue 2: 400-418.

Grubovic Lj., 2006 Belgrade in transition: An analysis of illegal building in a post-socialist city. $\mathrm{PhD}$ thesis, Proquest, Michigan.

Hutchison A., 2014 «The Whanganui River as a Legal Person» in Alternative Law Journal, vol. XXXIX, issue 3: 179-182.

Ingold T., 2012 Epilogue in Benediktsson, K., Lund, K. A. (ed.), Conversations with landscape. Anthropological Studies in Creativity and Perception, Ashgate, Farnham: 241-251.

Le Normand B., 2014 Designing Tito's Capital: Urban Planning, Modernism, and Socialism in Belgrade, University of Pittsburgh Press, Pittsburgh.

Lowenthal D., 1985 The Past is a Foreign Country, Cambridge University Press, Cambridge.

Mattei U., Quarta A., 2015 «Right to the City or Urban Commoning? Thoughts on the Generative Transformation of Property Law» in IUC Research Commons, International University College of Turin: 2-15.

Nicic M., Iguman S., 2019 «Post-socialism and “ordinary” tourism: New Belgrade» in International Journal of Tourism Cities, V, No. 3: 307-325.

Prideaux B., Timothy D., Cooper M., 2009 «Introducing river tourism: Physical, ecological and human aspects» in River Tourism, CABI Publishing, Wallingford:1-21. 
Sassen S., 1996 «Cities and Communities in the Global Economy: Rethinking Our Concepts» in American Behavioral Scientist, 39 (5): 629-639.

Sava River Basin Analysis Summary

http://www.savacommission.org/dms/docs/dokumenti/documents_publications/publications/ sava_river_basin_analysis_-_summary/sava_booklet_eng.pdf (last accessed Aug 2, 2021).

Trag fondacija

https://tragfondacija.org/en/active-communities (last accessed Sep 3, 2021).

United Nations Department of Economic and Social Affairs

https://www.un.org/en/desa/around-25-billion-more-people-will-be-living-cities-2050-projectsnew-un-report (last accessed July 2, 2021).

Vasiljevic J., 2019 «Social Engagement and Personal Activism: Some Research Reflections and Fieldnotes from Conversations with Activists in Two Belgrade Protest Initiatives» in M. Ivković, S. Prodanović (ed.), Engaging (for) Social Change. Towards New Forms of Collective Action, IFDT, Belgrade: 304-317.

Za naš kej - Facebook

https://www.facebook.com/ZaNasKej (last accessed Sep 10, 2021).

\section{APPENDIXES}

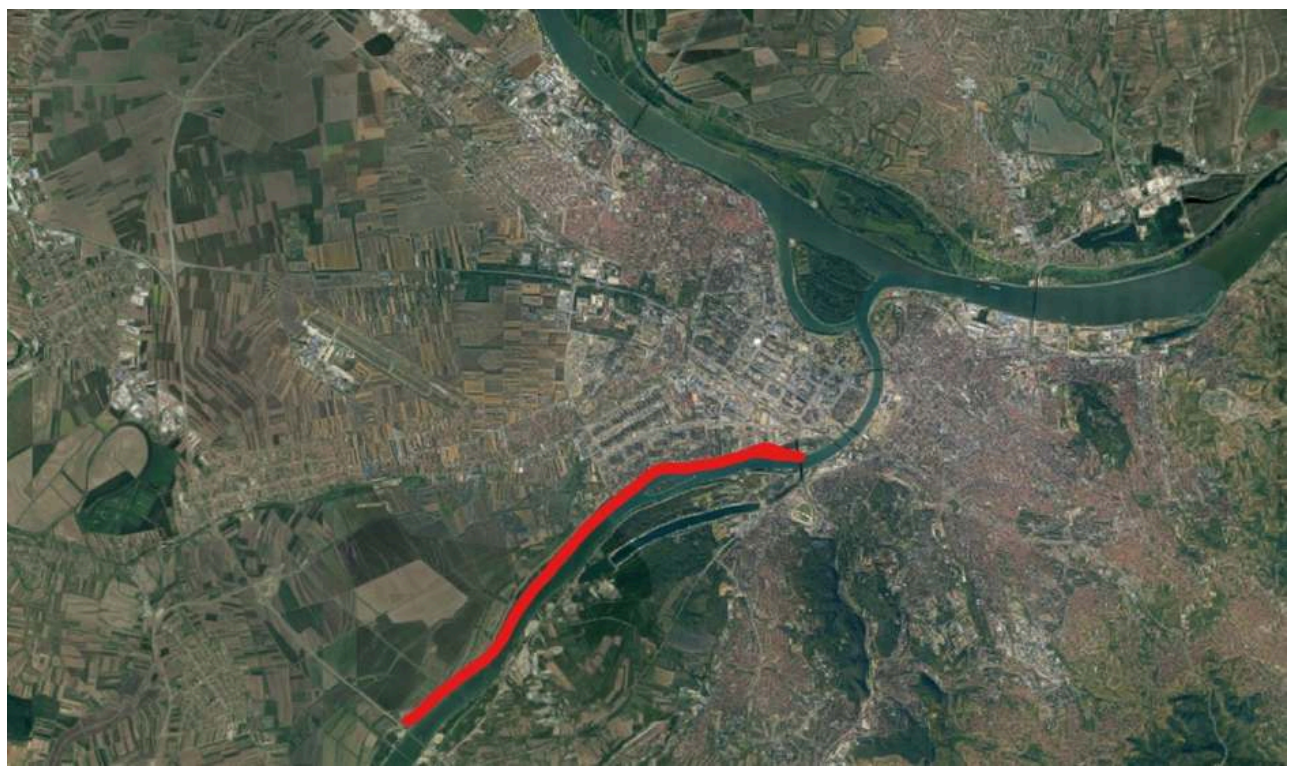

Picture 1. The left riverbank of Sava in New Belgrade. Source: Google map. 


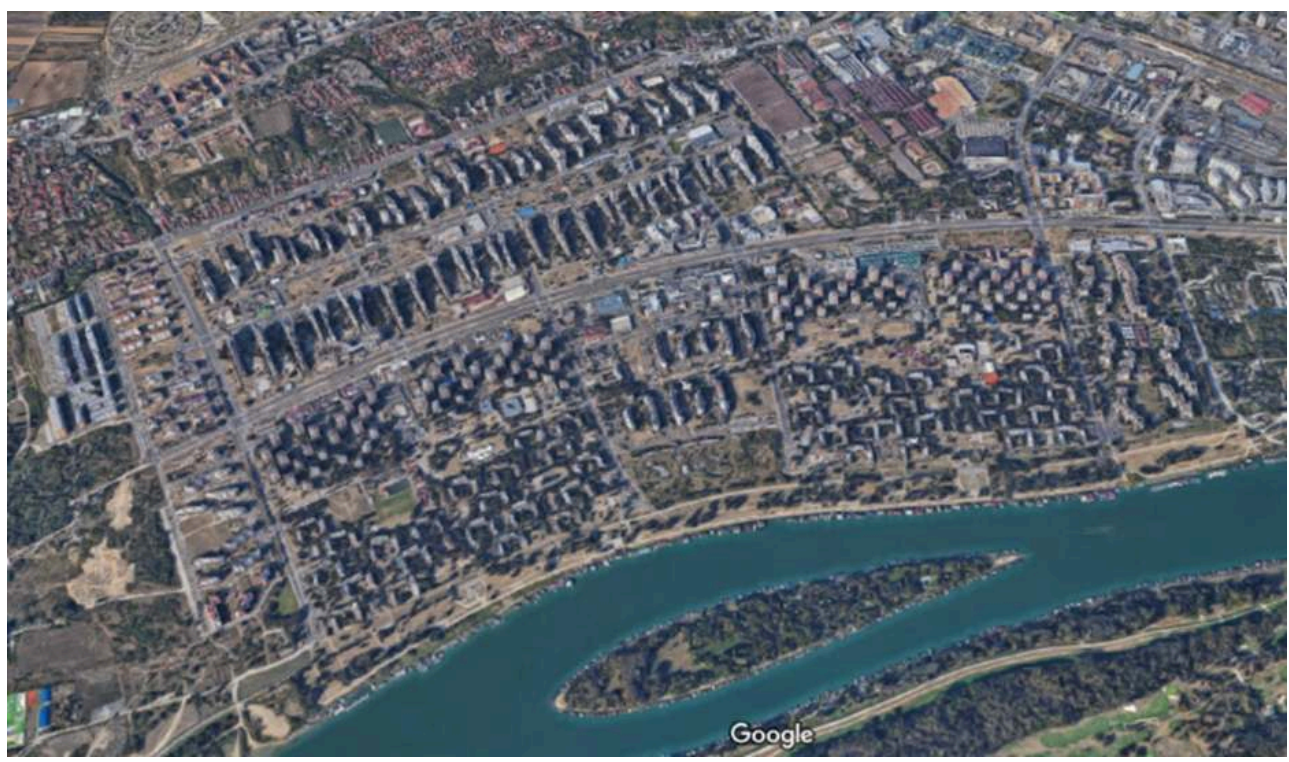

Picture 2. Satellite map of the blokovi next to the river Sava. Source: Google map.

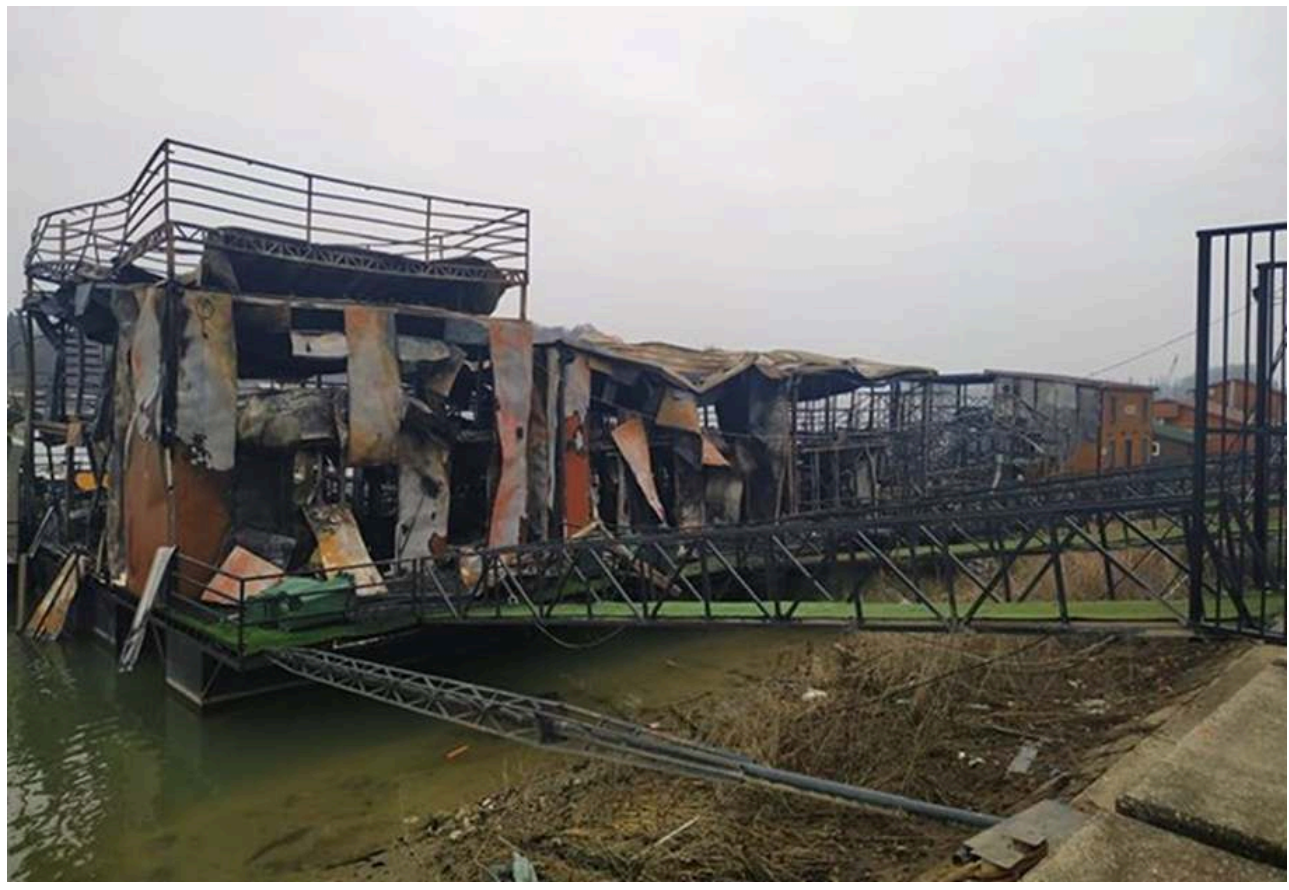

Picture 3. This photo shows several problems: Illegal floating night-clubs; illegal electric and water installations that brought to a major fire; a view over the river that is completely blocked; polluted water by litter thrown from these floating objects. January 2020. Source: Za nas kej. 


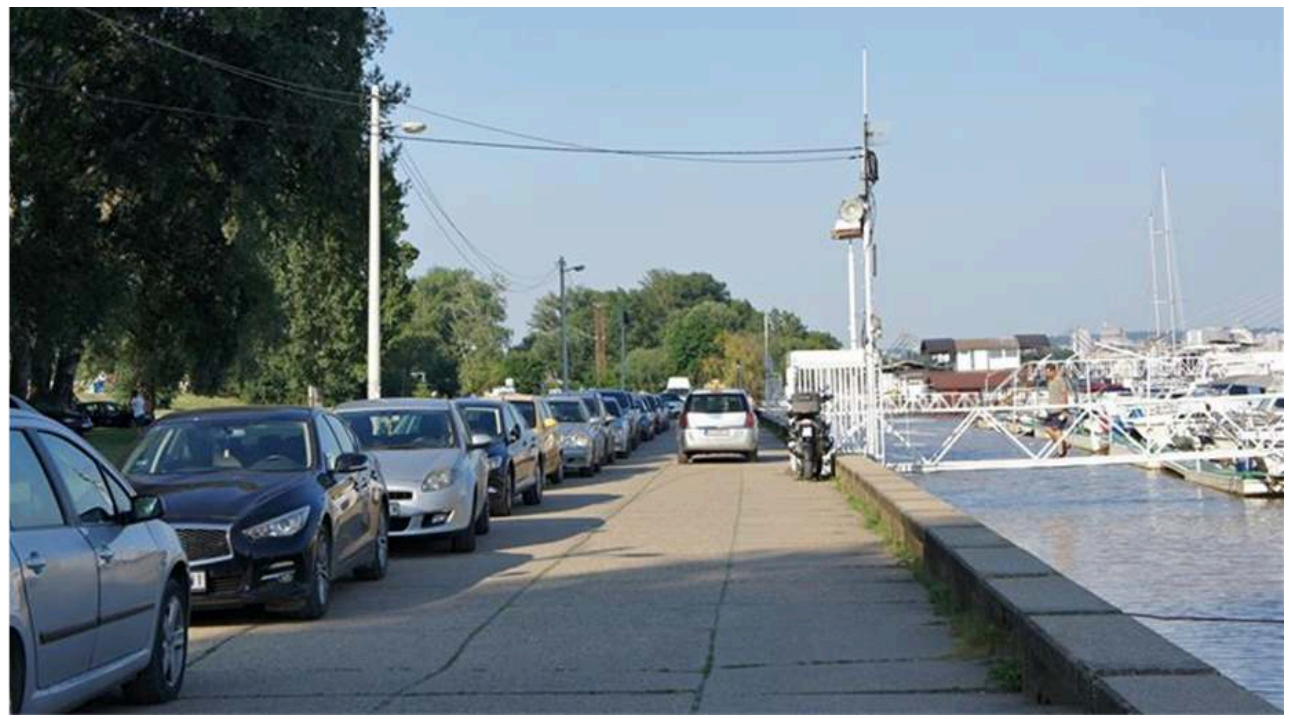

Picture 4. The Sava's quay is a pedestrian zone, but some owners and visitors of the floating objects are using it as a parking space. August 2020. Source: Za nas kej.

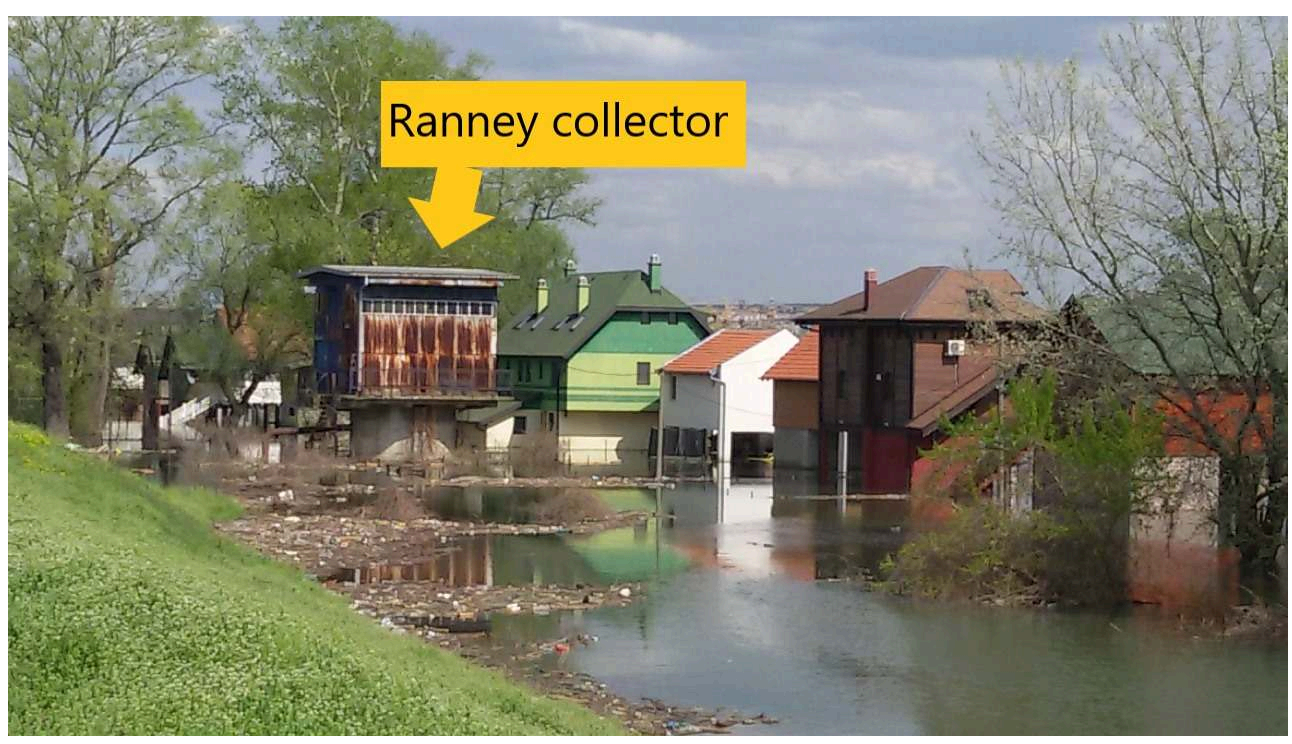

Picture 5. Illegal houses close to the water collector. 2018. Source: Savski nasip. 


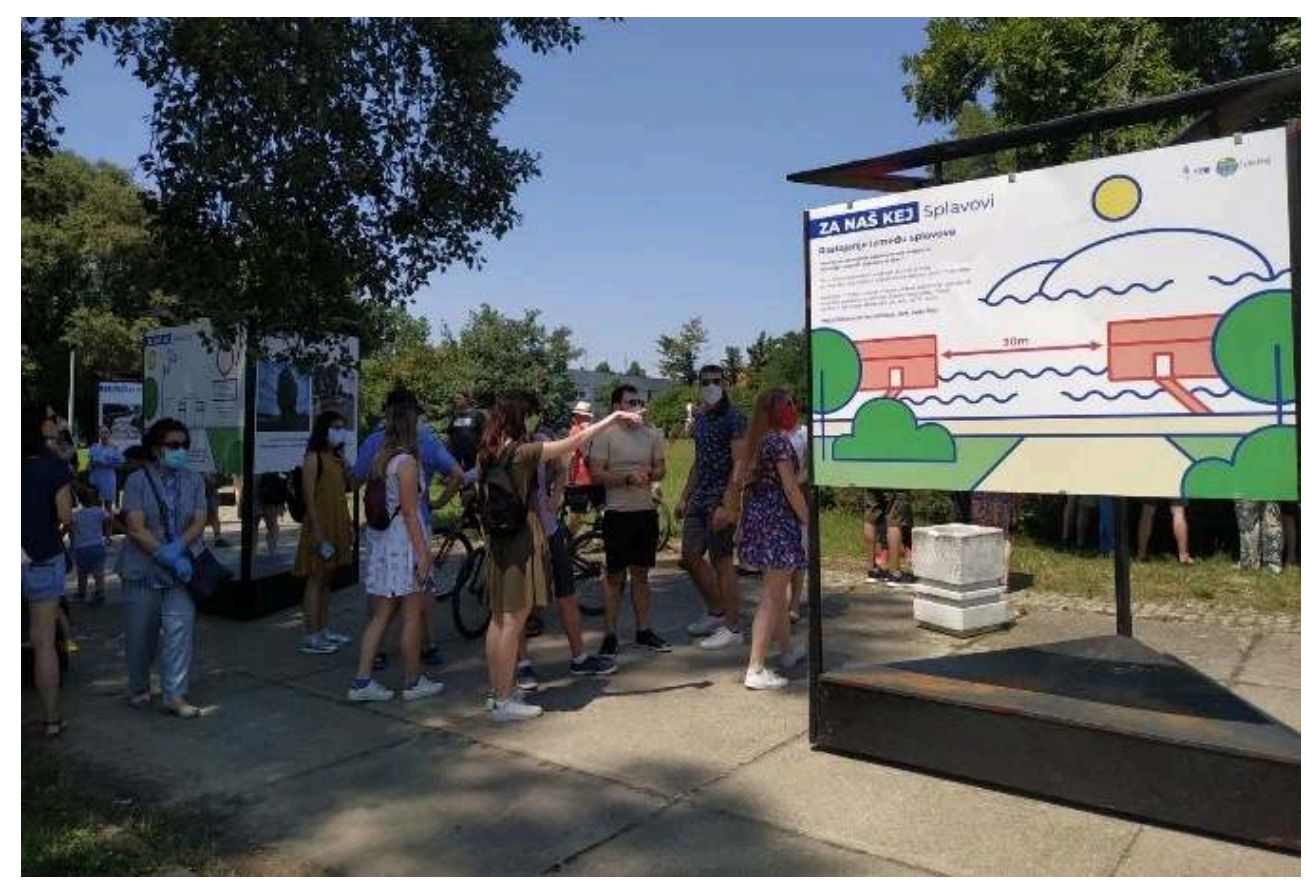

Picture 6. The opening of the exhibition on 28.6.2020. Source: Za nas kej.

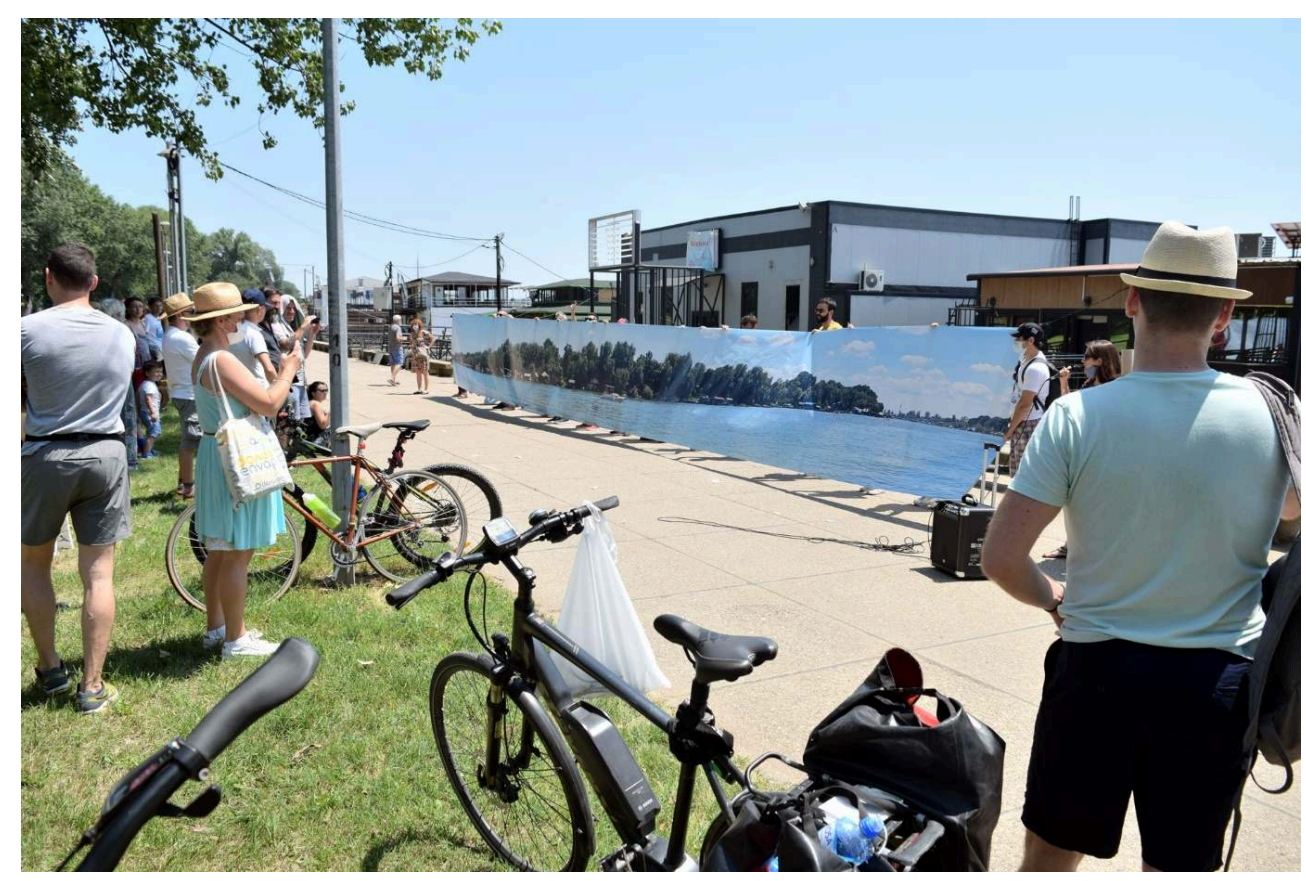

Picture 7. Activists showing $15 \mathrm{~m}$ long photograph at the exhibition opening, 28.6.2021. Source: Za nas kej.

\section{NOTES}

1. www.un.org/en/desa/around-25-billion-more-people-will-be-livingcities-2050-projects-new-un-report.

2. https://theculturetrip.com/europe/serbia/articles/dont-drown-belgradewhy-belgrade-is-protesting-the-waterfront-development.

3. http://7mostendangered.eu/sites/belgrade-fortress-and-its-surroundings-serbia. 
4. www.youtube.com/watch?v=-Fpn8SGm5gU\&ab_channel=Beogradvekovnigrad.

5. All listed urban-mega projects have been extremely controversial and in the spotlight by both national and international media. All of these projects have provoked strong citizens ' reactions against them, still, only the Kalemegdan cable car has been stopped (at least for the moment), while the others have been launched.

6. www.savacommission.org/basin_about.

7. https://drive.google.com/file/d/1GUUn_7MIzNQ3Yhtqnk2_z0hA67BKUlbE/view.

8. www.facebook.com/ZaNasKej/photos/pcb.940246023245781/940245533245830.

9. The best insight into this particular situation is provided by an unofficial group of citizens Savski nasip that gathers around 100.000 followers on Facebook, after being active for several years now: www.facebook.com/savskinasip.

10. https://en.wikipedia.org/wiki/Ranney_collector.

11. https://nedavimobeograd.rs/english.

12. www.budihuman.rs/en.

13. www.google.com/search?q=belgrade+waterfront+setaliste\&rlz=1C1GGRV_ enIT857IT857\&sxsrf=AOaemvLMCEDoDop5_dqVJ01Gmo6rt3spKA:

$1631110275025 \&$ source $=\operatorname{lnms} \&$ tbm=isch\&sa=X\&ved=2ahUKEwiXpKCkx-_yAhXCyKQKHQJ4D_0Q AUoAXoECAEQAw\&biw=1366\&bih=625.

14. Trag Foundation is a foundation that supports local initiatives in Serbia through their programs. Za nas kej recognized this opportunity, applied twice for the financial support and won the public competition in the program "Active communities".

15. www.paragraf.rs/propisi/pravilnik_o_opstim_pravilima_za_parcelaciju_regulaciju_ i_izgradnju.html.

16. www.facebook.com/watch/?v=3593948917509473.

17. https://rsf.org/en/serbia.

18. www.rferl.org/a/serbia-lithium-mine-protests/31455625.html.

19. https://balkangreenenergynews.com/serbia-to-sell-jaroslav-cerni-water-institute.

\section{ABSTRACTS}

The present paper focuses on the area of the Serbian capital marked off by two transnational rivers, the Sava and the Danube and by their confluence, which determined the birth and development of Belgrade. This area, target of radical and illegal urban transformations in the last decade, is analysed focusing on local activist groups' engagements and their reactions to these dynamics. The case explored is a specific place in Belgrade: river Sava and the banks in the vicinity of the confluence. This is a perfect example of landscape intended as a multi-layered concept that connects natural resources, human-made elements and most important - the people and their movements, actions, narration, emotions and relations. The paper describes how this place has been transformed through time, in cultural, ecological and physical sense, and it will mostly analyse the social consequences that the mentioned transformations have left on local citizens and on the way they are reacting to that, gathered in the neighbourly, activist groups.

Il contributo si concentra sull'area della capitale serba delimitata da due fiumi transnazionali, la Sava e il Danubio e dalla loro confluenza, che hanno determinato la nascita e lo sviluppo di 
Belgrado. Quest'area, oggetto di trasformazioni urbane radicali e illegali, viene analizzata focalizzandosi sugli impegni e le reazioni dei gruppi di attivisti locali a queste dinamiche. Il caso esplorato è un luogo specifico di Belgrado: il fiume Sava e le sue sponde, un perfetto esempio di luogo, un paesaggio inteso come un concetto a più livelli che collega risorse naturali, elementi creati dall'uomo e, soprattutto, le persone e l'invisibile: movimenti, azioni, narrazione, emozioni e relazioni. Il saggio descrive come questo luogo si sia trasformato nel tempo, in senso culturale, ecologico e fisico, e analizza principalmente le conseguenze sociali che queste trasformazioni hanno lasciato sui cittadini locali e sul modo in cui attivisti riuniti in gruppi di quartiere stanno reagendo.

INDEX

Keywords: activism, Belgrade, citizens, landscape, river

Parole chiave: attivismo, Belgrado, cittadini, fiume, paesaggio

\section{AUTHOR}

\section{SANJA IGUMAN}

Institute for Philosophy and Social Theory, University of Belgrade sanja.iguman@instifdt.bg.ac.rs 